\title{
ENURESIS AMONG SCHOOL-ENTRANTS IN THE CHANGING POPULATION OF ISRAEL
}

\author{
BY \\ J. THAUSTEIN AND H. S. HALEVI \\ Ministry of Health, Jerusalem, Israel
}

Children generally acquire bladder control at the age of 3 to 4 years, but some fail to achieve this control at the appropriate age. Since enuresis is a source of suffering for the child and his parents and may have secondary effects on the child's emotional development, pediatricians, general practitioners, child psychiatrists, psychologists, and educators concerned themselves with this problem.

Many theories have been advanced to explain the aetiology and pathogenesis of enuresis. Somatic factors, familial and constitutional factors, disorders of personality, and environmental conditions have been suggested as influencing enuresis.

The medical literature on enuresis has been reviewed by Dimson (1959) and Bakwin (1961). The papers mentioned in these reviews deal almost exclusively with children brought up in Western countries where conditions of life and patterns of child-rearing are comparatively well-established and are not undergoing major changes. Surveys carried out in Israel (Caplan, 1954; Levin, 1956; Kafman, 1957) have described the problem of enuresis among children of Western parentage in the communal settlements (kibbutzim). We have had the impression that the problem of bed-wetting has its peculiar public health aspects in Israel in the special conditions of a country of immigration. During the last 15 years over a million immigrants have entered Israel, more than doubling the previous population. The majority came from the Near East and North Africa, and these newcomers have undergone a profound process of social adjustment and cultural adaptation in an entirely new environment. The possibility of comparing them with the stable population caused us to concentrate mainly on the possible environmental causation of enuresis and the relationship between social-cultural patterns and the disorder.

A similar method of reasoning was noted by the
Expert Committee on Epidemiology of Mental Disorders (W.H.O., 1960) in regard to the examination of socio-cultural change in relation to the distribution of psychiatric disorders: "If high correlations were found between social change and disorganization and psychiatric disorder, and conversely a relative lack of disorder in the stable sector of the population, there would be an opportunity to gather evidence on the kinds of disorders most likely to be related to environmental conditions".

\section{Method and Scope of Present Inouiry}

On entering the elementary school at the age of about 6 , each child undergoes a physical inspection by a public health nurse, in order to discover existing contagious diseases or gross defects. At this opportunity a history of the child's health and development is taken from the mother. This examination was used in the present study to obtain information on bladder training, its success or failure. Nurses in Government Public Health Services in all parts of the country who volunteered to participate and fill out a special questionnaire were included. This was not a systematic representative sample of the whole school entrant population, but we received 2,280 completed questionnaires in which different strata of population were represented: old timers and newcomers, urban and rural, westernized and oriental, of different occupations and of different income and educational levels. Only cases of regular wetting, by night and/or by day, at least twice a week were considered as wetters. Children from the communal settlements (kibbutzim) and the Arab population were not included.

In the governmental elementary schools, which comprise under the law of compulsory education almost the whole school population of the country, two types are to be distinguished: secular and religious. The total of new entrants for the scholastic 
year $1959 / 60$ was 30,797 to the secular and 17,191 to the religious schools. Our sample comprises about 5 per cent. of all entrants, 6 per cent. in the secular and 3 per cent. in the religious schools (Table I).

TABLE I

CHILDREN INCLUDED IN SAMPLE, BY TYPE OF SCHOOL AND SEX

\begin{tabular}{|c|c|c|c|c|}
\hline \multirow{2}{*}{$\begin{array}{l}\text { Type of } \\
\text { School }\end{array}$} & \multicolumn{3}{|c|}{ Sex } & \multirow{2}{*}{$\begin{array}{c}\text { Proportion of } \\
\text { Total New } \\
\text { Entrants (\%) }\end{array}$} \\
\hline & Male & Female & Total* & \\
\hline $\begin{array}{l}\text { Secular } \\
\text { Religious }\end{array}$ & $\begin{array}{l}850 \\
226\end{array}$ & $\begin{array}{l}795 \\
229\end{array}$ & $\begin{array}{r}1,775 \\
505\end{array}$ & $\begin{array}{l}5 \cdot 8 \\
2.9\end{array}$ \\
\hline Total & 1,076 & 1,024 & 2,280 & $4 \cdot 8$ \\
\hline
\end{tabular}

-Including cases in which sex was not stated.

\section{RESUlTS}

AGE AND SEX.-The proportion of children who did not control the bladder at the age of school entrance was 15.5 per cent (Table II). It was considerably higher in the religious ( 19.6 per cent.) than in the secular schools (14.3 per cent.), and this difference is significant (S.E. 2 72 times the difference; $P<0.05$ ).

The difference between the sexes is not significant and does not show a constant trend (Table II).

TABLE II

PERCENTAge OF ENURETIC CHILDREN, BY SEX AND TYPE OF SCHOOL

\begin{tabular}{|c|c|c|c|c|c|}
\hline \multirow{2}{*}{\multicolumn{3}{|c|}{ Sex }} & \multicolumn{3}{|c|}{ Type of School } \\
\hline & & & Secular & Religious & All Schools \\
\hline $\begin{array}{l}\text { Male } \ldots \\
\text { Female . . } \\
\text { Not Stated }\end{array}$ & $\begin{array}{l}\cdots \\
\cdots \\
\cdots\end{array}$ & $\begin{array}{l}\cdots \\
\cdots\end{array}$ & $\begin{array}{l}13 \cdot 6 \\
14 \cdot 2 \\
19 \cdot 2\end{array}$ & $\begin{array}{l}20 \cdot 8 \\
18 \cdot 8 \\
18 \cdot 0\end{array}$ & $\begin{array}{l}15 \cdot 1 \\
15 \cdot 2 \\
18 \cdot 9\end{array}$ \\
\hline Total & .. & . & $14 \cdot 3$ & $19 \cdot 6$ & $15 \cdot 5$ \\
\hline
\end{tabular}

This is contrary to the findings of a number of other investigators (Bakwin and Bakwin, 1960) who found more wetters among boys than among girls.

The age of entrance to the elementary school in Israel is 6 years, and children less than 5 years and 8 months old at the beginning of the scholastic year are not admitted. Among new immigrants, especially from the oriental countries, they may enter at a considerably later age, and therefore had a range from under 6 to over 7 years of age (Table III). The percentage of wetting children does not vary greatly in the younger age groups, but there is a very considerable increase from the ages below 7 to the group aged "7 and over". Although the number of children included in these two groups is unequal, the difference between 15 per cent. "wet" children in the three younger groups combined and 27.9 per cent. in the older group is statistically significant (S.E. $2 \cdot 4$ times the difference; $P<0.05$ ).

TABLE III

PERCENTAGE OF ENURETIC CHILDREN, BY AGE AND SEX

\begin{tabular}{|c|c|c|c|c|c|}
\hline \multirow{2}{*}{$\begin{array}{c}\text { Age } \\
\text { (yrs) }\end{array}$} & \multirow{2}{*}{$\begin{array}{l}\text { No. of } \\
\text { Children }\end{array}$} & \multicolumn{4}{|c|}{ Sex (per cent.) } \\
\hline & & Male & Female & $\begin{array}{c}\text { Not } \\
\text { Stated }\end{array}$ & Total \\
\hline $\begin{array}{l}\text { Under } 6 \\
6 \text { and Under } 6 \cdot 5 \\
6 \cdot 5 \text { and Under } 7 \\
7 \text { and Over } \quad . . \\
\text { Not Stated } \quad .\end{array}$ & $\begin{array}{r}463 \\
1,322 \\
384 \\
68 \\
43\end{array}$ & $\begin{array}{l}15 \cdot 1 \\
14 \cdot 0 \\
16 \cdot 9 \\
27 \cdot 6 \\
17 \cdot 6\end{array}$ & $\begin{array}{l}14 \cdot 1 \\
15 \cdot 0 \\
14 \cdot 3 \\
32 \cdot 1 \\
18 \cdot 7\end{array}$ & $\begin{array}{l}18 \cdot 2 \\
18 \cdot 2 \\
15 \cdot 8 \\
18 \cdot 2 \\
40 \cdot 0\end{array}$ & $\begin{array}{l}14 \cdot 9 \\
14 \cdot 8 \\
15 \cdot 6 \\
27 \cdot 9 \\
23 \cdot 3\end{array}$ \\
\hline Total ... & 2,280 & $15 \cdot 1$ & $15 \cdot 2$ & $18 \cdot 9$ & $15 \cdot 5$ \\
\hline
\end{tabular}

ETHNIC ORIGIN.-In a heterogeneous population like that of Israel, which has arrived from different parts of the world at various periods, there are wide differences in cultural and economic conditions, which influence the pattern of child-rearing. Owing to small numbers of cases, however, it was impossible to combine the analyses by country of origin and year of immigration, and we had to consider each factor separately.

Among children of Israeli parentage (who are a mixture of all "origins" represented in the country), the percentage of "wetting" was $14 \cdot 6$, a little below the average for the whole sample $(15.5$ per cent.). Among immigrants, the percentage of wetting decreased with the length of stay in the country. For the last-comers, who are not yet fully absorbed and are still struggling to find their way in new surroundings, the percentage is higher.

The percentage of wetters among children of parents who immigrated at different periods was as follows:

\begin{tabular}{c|c}
\hline Date of Immigration & Percentage Wetters \\
\hline Before 1948 & $13 \cdot 9$ \\
$1948-1951$ & $15 \cdot 1$ \\
$1952-1955$ & $17 \cdot 1$ \\
Since 1956 & $18 \cdot 3$ \\
\hline
\end{tabular}

There was a very clear distinction between immigrants from European and oriental countries. Israelis occupy a middle position, as could be expected from their mixed composition. The immigrants from Iraq form the only exception in this picture, being similar to the Europeans (Table IV, overleaf). 
TABLE IV

PERCENTAGE OF ENURETIC CHILDREN, BY PARENTS' PLACE OF ORIGIN

\begin{tabular}{|c|c|c|c|}
\hline Place of Origin & No. of & Enur & S.E. \\
\hline 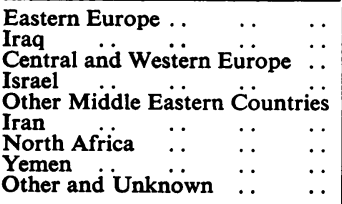 & $\begin{array}{r}723 \\
168 \\
225 \\
226 \\
154 \\
94 \\
548 \\
75 \\
67\end{array}$ & $\begin{array}{l}10 \cdot 1 \\
11 \cdot 9 \\
12 \cdot 0 \\
14 \cdot 6 \\
18 \cdot 8 \\
20 \cdot 2 \\
21 \cdot 0 \\
29 \cdot 3 \\
22 \cdot 4\end{array}$ & $\begin{array}{l} \pm 1 \cdot 12 \\
\pm 2 \cdot 50 \\
\pm 2 \cdot 16 \\
\pm 2 \cdot 35 \\
\pm 3 \cdot 15 \\
\pm 4 \cdot 14 \\
\pm 1 \cdot 74 \\
\pm 5 \cdot 25 \\
\pm 5 \cdot 09\end{array}$ \\
\hline
\end{tabular}

Occupation and Social Status.-The country of origin and the period of immigration are indicators of the economic and occupational status of the family. Only the most "populated" occupations were selected for analysis. In Israel the occupational groups are not in general clearly defined for sociological research, and broad groupings are therefore preferable (Table V).

In all three place-of-origin groups the hired manual workers have the highest percentages of wetting children. The difference between skilled and unskilled workers is not pronounced among Europeans and among Israelis it is small but it is clearly evident among orientals. Children of agriculturists show the lowest percentage of wetters among orientals; among Europeans they come midway between labourers and the urban middle-classes. Agriculture represents a much lower economic level among orientals than among Europeans and Israelis, and it is the only occupation in which orientals show a lower percentage than Europeans. A similar observation was made in the United Kingdom (Blomfield and Douglas, 1956) that "the lowest incidence of bedwetting was among children of the relatively prosperous professional and salaried groups and among the children of agricultural workers".

The economic status of the family can be deduced from the presence of permanent and full-time employment. The groups were too small for analysis in each occupation separately, but when they are taken together, the following percentages of wetters are $z$ seen:

\begin{tabular}{c|c}
\hline Father's Employment & Percentage Wetters \\
\hline Permanent & $13 \cdot 8$ \\
Temporary & $19 \cdot 8$ \\
Full-time & $12 \cdot 5$ \\
Part-time & $20 \cdot 8$ \\
\hline
\end{tabular}

These differences are statistically significant.

Education of Parents. - The educational background of the parents may play an important part in the rearing of children. This factor was analysed $?$ by ascertaining the type of the last school attended $\vec{\sigma}$ by both father and mother. Traditional old-type schools (the so-called Heder), where mainly Jewish to religious subjects (including Hebrew reading, writing, 음 and arithemetics) are taught, were included (Table VI).

TABLE VI

PERCENTAGE OF ENURETIC CHILDREN, BY PARENTS' EDUCATIONAL BACKGROUND

\begin{tabular}{|c|c|c|c|c|c|c|}
\hline \multirow{2}{*}{\multicolumn{3}{|c|}{$\begin{array}{l}\text { Type of School } \\
\text { last Attended }\end{array}$}} & \multicolumn{2}{|c|}{ Father } & \multicolumn{2}{|c|}{ Mother } \\
\hline & & & \multirow{2}{*}{$\begin{array}{c}\begin{array}{c}\text { No. of } \\
\text { Chil- } \\
\text { dren }\end{array} \\
208\end{array}$} & \multirow{2}{*}{$\begin{array}{c}\begin{array}{c}\text { Percent- } \\
\text { age of } \\
\text { Wetters }\end{array} \\
29 \cdot 3\end{array}$} & \multirow{2}{*}{$\begin{array}{c}\begin{array}{c}\text { No. of } \\
\text { Chil- } \\
\text { dren }\end{array} \\
40\end{array}$} & \multirow{2}{*}{$\begin{array}{c}\begin{array}{c}\text { Percent㐫 } \\
\text { age of } \\
\text { Wetters }\end{array} \\
25 \cdot 0\end{array}$} \\
\hline Traditional & 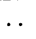 & $\cdots$ & & & & \\
\hline Elementary & \multicolumn{2}{|c|}{$\begin{array}{l}\text { Not completed } \\
\text { Completed .. }\end{array}$} & $\begin{array}{l}454 \\
648\end{array}$ & $\begin{array}{l}14 \cdot 8 \\
15 \cdot 9\end{array}$ & $\begin{array}{l}500 \\
597\end{array}$ & $\begin{array}{l}17 \cdot 4 \\
12 \cdot 1\end{array}$ \\
\hline Secondary & \multicolumn{2}{|c|}{$\begin{array}{l}\text { Not completed } \\
\text { Completed } \ldots\end{array}$} & $\begin{array}{l}206 \\
332\end{array}$ & $\begin{array}{r}14 \cdot 1 \\
8 \cdot 4\end{array}$ & $\begin{array}{l}232 \\
303\end{array}$ & $\begin{array}{l}12 \cdot 1 \\
10 \cdot 6\end{array}$ \\
\hline University & $\cdots$ & $\cdots$ & 153 & $12 \cdot 4$ & 60 & $16 \cdot 7$ \\
\hline \multicolumn{3}{|c|}{ None and Unknown } & 279 & $16 \cdot 5$ & 548 & $20 \cdot 8$ \\
\hline Total .. & & $\cdots$ & 2,280 & $15 \cdot 5$ & 2,280 & $15 \cdot 5$ \\
\hline
\end{tabular}

There is no significant difference between the groups according to the education of either father or mother. With rising educational standards, which

TABLE $\mathrm{V}$

PERCENTAGE OF ENURETIC CHILDREN, BY FATHER'S ORIGIN AND OCCUPATION

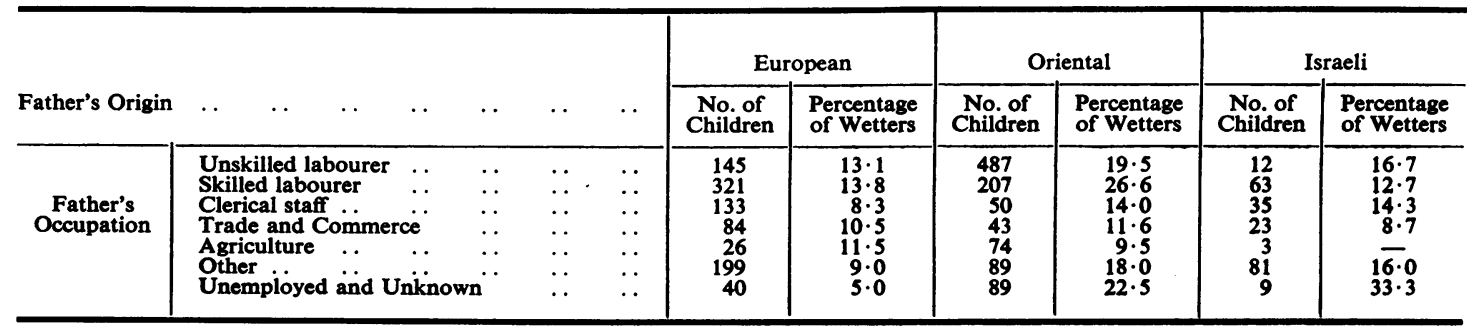


is also an expression of the socio-economic status of the family, the percentage of wetting children declines. A surprising exception is formed by the parents who attended universities. It seems that sophisticated parents are relatively unsuccessful in achieving cleanliness in their children at the proper age.

Housing Conditions. - In a country of recent mass-immigration, housing conditions are difficult and many people sometimes have to stay for considerable periods in transitory dwellings. The connexion between enuresis and housing conditions was investigated from several points of view.

The period that had elapsed since the family had entered the permanent home seems to be of importance. In families which were settled permanently for less than 2 years, 20 per cent. of the children were wet, as against only 11.5 per cent. in families with a longer stay in permanent housing. It should be remembered, however, that this point is identical to a high degree with length of stay in Israel, a point already discussed. We were surprised to find that outside toilet facilities had no effect on the prevalence of enuresis.

Only $11 \cdot 3$ per cent. of the children had a separate bedroom, all the rest having to share with parents, siblings, or others (mostly grandparents). The percentage of wet children was $5 \cdot 1$ among the first group, as against 16.7 per cent. in the second. There was no significant difference between children who had a separate bed in a shared bedroom and those who shared a bed with others.

The country of origin is reflected to a certain extent in the sleeping conditions. Children of European and Israeli origin had to share a bed only in about 5 per cent. of cases, while among children from oriental communities the sharing a bed rose to about 50 per cent. A special survey would be needed to distinguish between the cultural and economic factors involved in this situation.

The weight of the housing factor can be appreciated when it is considered against the background of the general housing conditions in Israel. A housing census taken on a sample in November, 1957 (Central Bureau of Statistics, 1958), revealed that only 44 per cent. of the population lived in a density of less than two persons per room. Almost 23 per cent. lived in highly over-crowded conditions of three and more persons per room. A considerable difference was found between the veteran population and the immigrants: this was 11.5 per cent. of heavy overcrowding in the first group and 33.3 per cent. in the second. The overcrowding was greater in rural areas than in the towns, the median number of persons per room being 1.9 in the towns as against 2.2 in the rural settlements (including kibbutzim).

EDUCATION FOR ClEANLINESS.-The 1,927 "clean" children were analysed in regard to the age when education for cleanliness started, according to the retrospective reply of the mother. In 374 cases mothers could not recall the age, in 117 cases it was stated that no educational efforts were made to achieve cleanliness, and for the rest, education began between the second quarter of the first year of life and the end of the second year. In only two cases was education started before the infant reached the age of 3 months. The connexion between the age of starting education and the age when cleanliness was achieved is not strong. The coefficient of correlation is +0.40 for bladder control and +0.42 for bowel control. Neither figure is significant $(0 \cdot 10>P>0 \cdot 05)$. Among "wet" children, the age when cleanliness education started was similar to that among "dry" children, and we may conclude that no significance is to be attached to this factor.

We did not ask what was the educational approach to achieve cleanliness, because of the unreliability of such data when recalled retrospectively, but the mothers of "wet" children were asked what means they were using at present in order to overcome the enuresis.

The influence of the cultural factor is evident in Table VII. Orientals used punishment in 39 per cent. of the cases, whereas among Europeans this means was limited to 15 per cent., Israelis coming, as in most cases, in the middle. Medical treatment was used more often among the Europeans, and in this respect the Israelis lagged behind the orientals. The most popular means of education in all groups was explanation and nagging.

TABLE VII

METHOD OF EDUCATION (PER CENT.) AGAINST ENURESIS, BY PLACE OF ORIGIN

\begin{tabular}{|c|c|c|c|c|}
\hline Method of Education & Total & European & Oriental & $\begin{array}{c}\text { Israeli } \\
\text { and } \\
\text { Unknown }\end{array}$ \\
\hline Total No. of Cases & 353 & 100 & 205 & 48 \\
\hline $\begin{array}{l}\text { Punishment } \\
\text { Reasoning and Scolding } \\
\text { Reward } \\
\text { Medical Treatment } \quad \ldots \\
\text { Other Treatment } \\
\text { No Educational Effort }\end{array}$ & $\begin{array}{l}30 \cdot 6 \\
53 \cdot 2 \\
1 \cdot 1 \\
5 \cdot 6 \\
0 \cdot 8 \\
8 \cdot 5\end{array}$ & $\begin{array}{r}15 \cdot 0 \\
63 \cdot 0 \\
1 \cdot 0 \\
9 \cdot 0 \\
2 \cdot 0 \\
10 \cdot 0\end{array}$ & $\begin{array}{r}39 \cdot 0 \\
47.9 \\
1.5 \\
4.9 \\
\frac{6.9}{}\end{array}$ & $\begin{array}{l}29 \cdot 5 \\
54 \cdot 6 \\
\overline{2 \cdot 3} \\
2 \cdot 3 \\
11 \cdot 4\end{array}$ \\
\hline
\end{tabular}

DAY AND Night WeTters. -86.4 per cent. of the "wet" children were wetting during the night only, a further 11.3 per cent. were wet by day and by night, and only $2 \cdot 3$ per cent. were day-wetters only. 
Siblings.-In 43 families we found siblings older than the index child who were not yet clean.

Other Behaviour Disorders.-Psychologists assume that other behaviour disorders may accompany enuresis (Bakwin, 1961). The mothers were asked about three symptoms of such disorders, but an answer was given in only half of the cases.

The differences between the two groups of children are small and even in the case of thumb-sucking statistically insignificant (Table VIII).

TABLE VIII

FREQUENCY OF BEHAVIOUR DISORDERS AMONG DRY AND WET CHILDREN (PERCENTAGES)

\begin{tabular}{|c|c|c|c|c|c|}
\hline \multicolumn{4}{|c|}{ Behaviour Disorders } & Dry & Wet \\
\hline $\begin{array}{l}\text { Thumb-sucking } \\
\text { Nail-biting } \\
\text { Nightmares }\end{array}$ & $\begin{array}{l}\cdots \\
\ldots \\
\ldots\end{array}$ & $\begin{array}{l}\ldots \\
\cdots\end{array}$ & $\begin{array}{l}\ldots \\
\cdots \\
\cdots\end{array}$ & $\begin{array}{r}36.9 \\
13.8 \\
5.0\end{array}$ & $\begin{array}{r}44.8 \\
12.7 \\
5.5\end{array}$ \\
\hline
\end{tabular}

\section{Discussion}

The average prevalence of enuresis at the age of 6 years was found to be 15.5 per cent. with no difference between boys and girls. In another survey (Zaslany, 1960) carried out on similar lines in the schools in Jerusalem, the proportion of enuretics found was 17.9 per cent. for boys and 15.7 for girls (the difference is not significant). These are higher percentages than are found in surveys in other countries. In Sweden (Hallgren, 1959) the proportion of enuretics after the age of 5 was found to be 12 per cent. for boys and 8 per cent. for girls. In Newcastle, England, an average was given of 8.9 per cent. for both sexes at the age of 5 (Miller, Court, Walton, and Knox, 1960). A much lower average percentage of bedwetters $(1 \cdot 71$ to $3 \cdot 81)$ was noted in another inquiry (Douglas and Blomfield, 1958), which stresses that "boys more often wetted their beds than girls". We have no explanation for the unusual likeness between the sexes in Israel.

In general, our rate of wetters is higher than has been found in studies of the problem abroad and we are therefore unable to confirm the finding of some investigators that "enuresis was more frequent among the non-Jewish than among the Jewish children" (Bakwin, 1961). It may be that social class is the influencing factor in this apparent ethnic difference. We are unable to exclude the possibility of influence by a bias which may have occurred in our sample because of the method of its selection, but we cannot verify this because of the lack of information on the origin, occupation, and educational background of parents of the general school population.

As mentioned above, children from communal settlements (kibbutzim) were not included in our material, since their schools are served by nongovernmental health services. Because of the special interest attached to the pattern of child-rearing in kibbutzim and its possible influence on the emotional development of the children some surveys have already been conducted in this specific field. Prof. Caplan of Harvard University, who lived and worked for a few years in Israel, found "that in kibbutzim in different parts of the country, the average incidence of enuresis was from 35 to 50 per cent." (Caplan, 1954). According to his estimate "this average among 5 -year-olds is about three times greater than that found in a survey of kindergarten children in Jerusalem, where the incidence of reported enuresis was 10 to 15 per cent.". This last figure approximates to ours, although we investigated the 6-year age group. Caplan stressed that signs of emotional disturbance, of which bed-wetting is one, fell rapidly as the children reached adolescence. By the time they reach the age of 10 or 11 , the signs of emotional disturbance among these children appear only about as frequentlis as they do among children brought up in our culture'To

Two other surveys by members of different coms munal settlements were inspired by the statements of Prof. Caplan. Levin (1956) found among 1,600 children aged 4 to 8 years 30.5 per cent. of wetters. In children in the 7 th year of life percentage was $21 \cdot 3$ ( 25 for boys, 18 for girls). Among the total group of wetters (aged 4 to 8 years) 59 per cent. were wetting at night only, 40 per cent. day-and-night, and only 1 per cent. by day only. This distribution deviates from our findings in having a higher proportion of day-and-night wetters (40 against $11 \cdot 3$ per cent.). These results substantiate the findings of Prof. Caplan. The second survey (Kafman, 1957) was conducted among 403 kibbutz children. The proportion of enuretics in the 7th year of life was only 12 per cent. The average for the whole group (aged $3 \frac{1}{2}-12 \frac{1}{2}$ ) was 11 per cent., and the author concludes that kibbutz children are in this respect no worse than children brought up in a normal family environment. There is an evident discrepancy between the findings of the two surveys, although both were taken in settlements based on the same ideological movement and with similar educational methods.

It seems from our material that ethnic and social factors play a decisive role in regard to enuresis. We did not deal with other aspects of aetiology, although psychosomatic and somatic influences may also enter 
the picture. It may be of interest to state that a physician who worked for over 5 consecutive years in a communal settlement and had the opportunity of very close supervision of its population, found that among 21 children who were enuretic after the age of 4 there were seven who had suffered at one time or another from spastic bronchitis or pseudo-croup. Three more children suffering from these symptoms, without being enuretics themselves, had enuretic siblings. In another kibbutz in the same practice, six bed-wetters were found among eighteen children who had had attacks of these two diseases and two more had enuretic siblings (Horetzki, 1960).

\section{Conclusions}

The average frequency of enuresis found in our study is higher than that given in surveys from other countries; this fact seems to be conditioned mainly by the socio-economic status and the security-stability of the population. Several of the variables analysed can be approached from this angle. Newcomers are facing difficult economic problems and live in congested conditions; the economic level of the families whose children attend religious schools is on the average lower than that of those whose children attend secular schools; and most of the indigent population belong to the oriental communities which have constituted the bulk of immigrants during the last decade. It is clear that the educational level of these strata of population shows an economic gradient. It seems, therefore, that the various factors connected with the frequency of enuresis centre in social dependency. A general improvement in the socio-economic conditions of the population and the cultural absorption of the immigrants give hope that the incidence of this symptom will be reduced in Israel in the future, whereas direct measures do not seem to be promising.

Thanks are due to the nurses in the Government Public Health Services who volunteered to participate in questioning the mothers in regard to enuresis, and to Mrs. E. Hochwald, Statistical Department of Ministry of Health, who was most helpful in processing the material.

\section{REFERENCES}

Bakwin, H. (1961). J. Pediat., 58, 806.

- and Bakwin, R. M. (1960). "Behaviour Disorders in Children", 2nd ed., p. 366. Philadelphia.

Blomfield, J. M., and Douglas, J. W. B. (1956). Lancet., $1,850$.

Caplan, G. (1954). "Problems of Infancy and Childhood": Trans. VII Conf., 1953, pp. 98, 102. Josiah Macy Jr. Foundation, New York.

Central Bureau of Statistics (1958). Statist. monthly Bull. Israel, Part I, 9, 1128 (in Hebrew).

Dimson, S. B. (1959). Brit. med. J., 2, 666.

Douglas, J. W. B., and Blomfield, J. M. (1958). "Children Under Five”, p. 130. Allen and Unwin, London.

Hallgren, B. (1959). Acta paediat., 48, Suppl. 118, p. 66.

Horetzki, H. (1960). Personal communication.

Kafman, M. (1957). Horizons (Ofakim), 11, 339 (in Hebrew).

Levin, G. (1956). Ibid., 10, 375 (in Hebrew).

Miller, F. J. W., Court, S. D. M., Walton, W. S., and Knox, E. G. (1960). "Growing Up in Newcastle upon Tyne, p. 150. Oxford University Press, London.

Zaslany, A. (1960). Personal communication.

World Health Organization (1960). "Epidemiology of Mental Disorders", Tech. Rep. No. 185, p. 28. W.H.O., Geneva. 